\title{
SUSTAINABLE VALUE CO-CREATION IN MOBILE ADVERTISING IN CELLULAR TELECOMMUNICATION INDUSTRY: A CONCEPTUAL FRAMEWORK
}

\author{
Joko Rurianto*), Ujang Sumarwan**), Budi Suharjo ${ }^{* * *}$, and Nur Hasanah") \\ *) School of Business, IPB University \\ Jl. Raya Pajajaran, Bogor 16151, Indonesia \\ **) Departement of Family and Consumer Sciences, Faculty of Human Ecology, IPB University \\ Campus IPB Dramaga Bogor 16680, Indonesia \\ **) Departement of Mathematics, Faculty of Mathematics and Natural Sciences, IPB University \\ Jl. Meranti, Campus IPB Dramaga Bogor 16680, Indonesia
}

\begin{abstract}
The growth of Mobile Internet services has changed the paradigm of telecommunication consumers from information- oriented toward social to communication- oriented. This change makes customers as part of the digital society, especially in Mobile Advertising services. Along with this change and the requirement for the company to win the competition, telecommunication providers must develop a business model of Mobile Advertising as a 'stage' that is easily accessible to all interested customers to this facility. In the concept of Service Dominant Logic, the company has no longer as a full control of value creation, but it must involve the customer in the process of value co-creation. The purpose of this research is to understandnding the landscape of Mobile Advertising services in telecommunication industry, understanding the existing model that can be build a model of Mobile Advertising services in the telecommunication industry, and understanding Mobile Advertising will influence on the value co-creation of the brand and corporate image. The research method using survey, exploratory, and systematic review. The research develops a model from the model of attributes and benefits of online community, model Consumer Engagement, model Attitude Toward Online Ads and model of Click Through Rate (CTR).
\end{abstract}

Keywords: value co-creation, mobile advertising, consumer engagement, attitude toward online ads, click through rate (CTR)

\begin{abstract}
Abstrak: Pertumbuhan layanan Mobile Internet telah mengubah paradigma konsumen telekomunikasi dari konsumen yang berorientasi pada informasi menjadi konsumen yang berorientasi pada sosial dan komunikasi. Perubahan ini menjadikan pelanggan sebagai bagian dari masyarakat digital. Seiring dengan perubahan ini dan kebutuhan perusahaan telekomunikasi untuk memenangkan persaingan di industri global, salah satu yang bisa dilakukan adalah perusahaan telekomunikasi harus mengembangkan model bisnis Mobile Advertising sebagai 'panggung' yang mudah diakses oleh semua pelanggan yang tertarik ke layanan ini. Dalam konsep Service Dominant Logic, perusahaan tidak lagi memegang kontrol secara penuh terhadap penciptaan nilai, tetapi harus melibatkan pelanggan dalam proses penciptaan nilai tersebut. Tujuan penelitian ini adalah untuk memahami layanan mobile advertising di industry Telekomunikasi saat ini, memahami berbagai model yang ada saat ini yang digunakan bersama-sama untuk membangun model di layanan mobile advertising, dan memahami layanan mobile advertising yang berpengaruh terhadap penciptaan nilai bersama dalam suatu perusahaan. Metode yang digunakan adalah berbasis survey, eksplorasi data dan systematic review. Penelitian ini mengembangkan model dari model atribut dan manfaat komunitas online, model Consumer Engagement, model Attitude Toward Online Ads, dan model Click Through Rate (CTR).
\end{abstract}

Kata kunci: penciptaan nilai bersama, mobile advertising, consumer engagement, attitude toward online ads, click through rate (CTR)

\footnotetext{
${ }^{1}$ Corresponding author:

Email: jokorurianto21@gmail.com
} 


\section{INTRODUCTION}

The world of marketing has entered a revolutionary new era. At a time when the effectiveness of traditional marketing communications is declining, a new method in the marketing world is undergoing significant development. The new method is known as "digital marketing" which combines psychological, humanist, demographic, psychographic, and technological factors through multimedia with a large and interactive capacity. The result is a new round of interaction between manufacturers, market intermediation, and consumers, with the medium of mobile technology as the dominant element (Aluri et al. 2015).

The rapid development of digital marketing is causing a change in consumer behavior, especially product search activities and information selection. This change prompted many manufacturers to turn to online media in advertising their products. Product promotion using online media has the advantage of not limited by space and time, consumers can access the ads anytime and anywhere. To maximize the promotion of products using digital marketing media, the seller must have differentiation factors that buyers need. Differentiation can be a differentiator in product dimensions, services, distribution (channel), people, or company image (Kotler and Armstrong, 2018). One way to create differentiation factors that last (sustainable) is by efforts to increase the value of co-creation. With value co-creation, it is expected that the seller will have a competitive advantage to win the competition, because there is a reciprocal relationship between the seller and the buyer.

In marketing relationships, customer purchasing decision making always involves individuals who are involved in purchasing activities. Therefore, purchasing decisions and continuity of business relationships or customer loyalty are influenced by rational aspects and emotional aspects (Kotler and Keller, 2016). Rational aspects such as product quality, technology, and after-sales service are more important than emotional aspects such as risk reduction, certainty, trust, and close relationships between companies and customers (Lin et al. 2018). Although the rational aspect is more important than the emotional aspectthe emotional aspects such as how to form a close reciprocal relationship between customers and the company still cannot be ignored completely, so it is necessary special research to establish the value co-creation factor to answer the question. How strong the influence of rational aspects of a product compared to the emotional aspect in the context of the formation of value co-creation, especially in the mobile advertising industry to the telecommunications market, became one of the research gaps in this study. Some previous research also confirms that there is no type of level in the value co-creation itself, especially the study of value co-creation in mobile advertising marketing in the telecommunications industry (Nihel, 2013). This is another research gap and one of the underlying things that this research is doing. To answer the research gap in this study will be explained several factors that shape value co-creation in the telecommunications industry, especially in mobile advertising services, namely consumer engagement, CTR (Click Through Rate), and attitude toward online ads.

Consumer engagement in online activity is defined as a consumer's contribution to the retrieval or exploration of content in an online activity site (Kankanhalli et al. 2005; Li and Bernoff, 2011). More and more consumer involvement in the organization will provide opportunities for the formation of greater and more valuable co-creation value for consumers. Previous research was built on the literature on consumer value, customer engagement, service dominant logic, value co-creation, customer participation and consumer behavior (Holbrook, 2006; Vivek, 2009; Lin et al. 2018). Some studies recognize the importance of values in marketing, both intrinsic and extrinsic values. Intrinsic value is obtained when the consumer realizes that his engagement initiative is for his own benefit or as a justification for himself (Holbrook, 2006). While extrinsic value is obtained if the engagement initiative allows consumers to do some activities better than before.

In the development of the mobile telecommunications industry, highly competitive market competition demands companies to continue innovating to launch new products. The mobile telecommunication industry market in Indonesia shows growth in the subscriber data sector, data from the Indonesian Central Bureau of Statistics (BPS, 2019) shows that subscriber data usage touches the number of hamper $10 \mathrm{~TB}$ per month with the most spread found in mobile web and mobile video usage (Figure 1). 


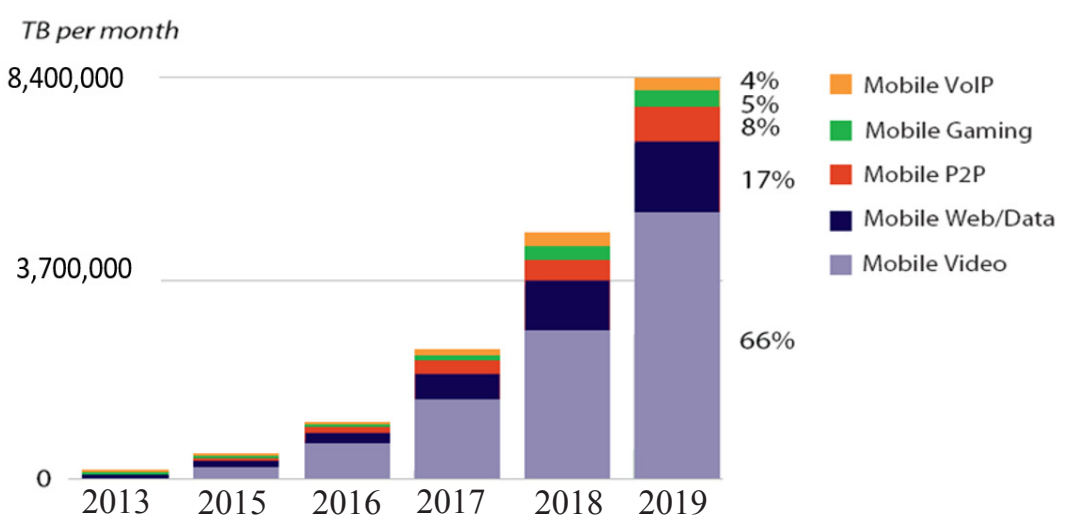

Figure 1. Data of useable internet mobile telecommunication Indonesia 2013-2018 (BPS, 2019)

The growth of internet data users is in line with Goldsmith et al. (2005) which states that the rapid development of data communication leads to changes in consumer behavior, especially product search and information selection activities. This change prompted many manufacturers to turn to online media in advertising their products. Product promotion using online media has the advantage of not limited by space and time, consumers can access the ads anytime and anywhere. This service is also called mobile advertising service (Ho and Ho, 2008). Mobile advertising service is a service that provides product information from advertisers (companies) to customers by utilizing wireless telephones and telecommunication networks as intermediaries. Efforts to continuously improve the effectiveness of mobile advertising service campaigns are the main challenges for marketers. On the other hand, with the increasing number of companies promoting their products through the internet, making competition between products that use this service increasingly tighter, it triggers companies and telecommunication operators as service owners to implement a different strategy with the aim of attracting new customers and retaining existing customers (Ho and Ho, 2008).

Furthermore, to test the strength of the influence of attitude toward online ads, a review of attitude toward online ads is conducted in relation to consumer engagement and click through rate (CTR). In a study conducted by Newman (2004), attitudes towards websites were found at a time when there was a congregant between advertising banners and websites, a condition of congruence was achieved when there was a match between banner ads and website types. In another study Korgaonkar and Wolin (2002) conducted testing on advertising value by only testing the variables of entertainment and informativeness only, without a wider study of the possibility of other variables that will affect customer satisfaction and co-creation value shaper.

\section{METHODS}

The data collection of this study was conducted from September 2020 to January 2021. This Methods for this research using survey, exploratory, and systematic review. This research also using more than 300 journal with a specific keyword "mobile advertising" or "value co-creation process", with the detail in Figure 2.

The selection of online communities in mobile advertising services in the telecommunications industry is based on online community criteria that reflect the trendsetters of the broadband industry in Indonesia. Various online community journals meet the rules of online community requirements according to Muniz et al. (2001) and are a community type help group or value exchange (Szmigin, 2005) because it is easily accessible to customers and generates shared value (Soehadi, 2012). The help group type is a community formed because of the similarity of interest among members, while the value exchange type prioritizes communication between customers to share professionally.

This paper will use the mix method; the secondary data is collected from government/institution, association, and statistical biro. meanwhile, primary data is taken from Focus Group Discussion (FGD) and the questionnaires. The questionnaires will be distributed directly to the business actors randomly. The research populations are users who use mobile advertising services to promote their product in last 3 years. 


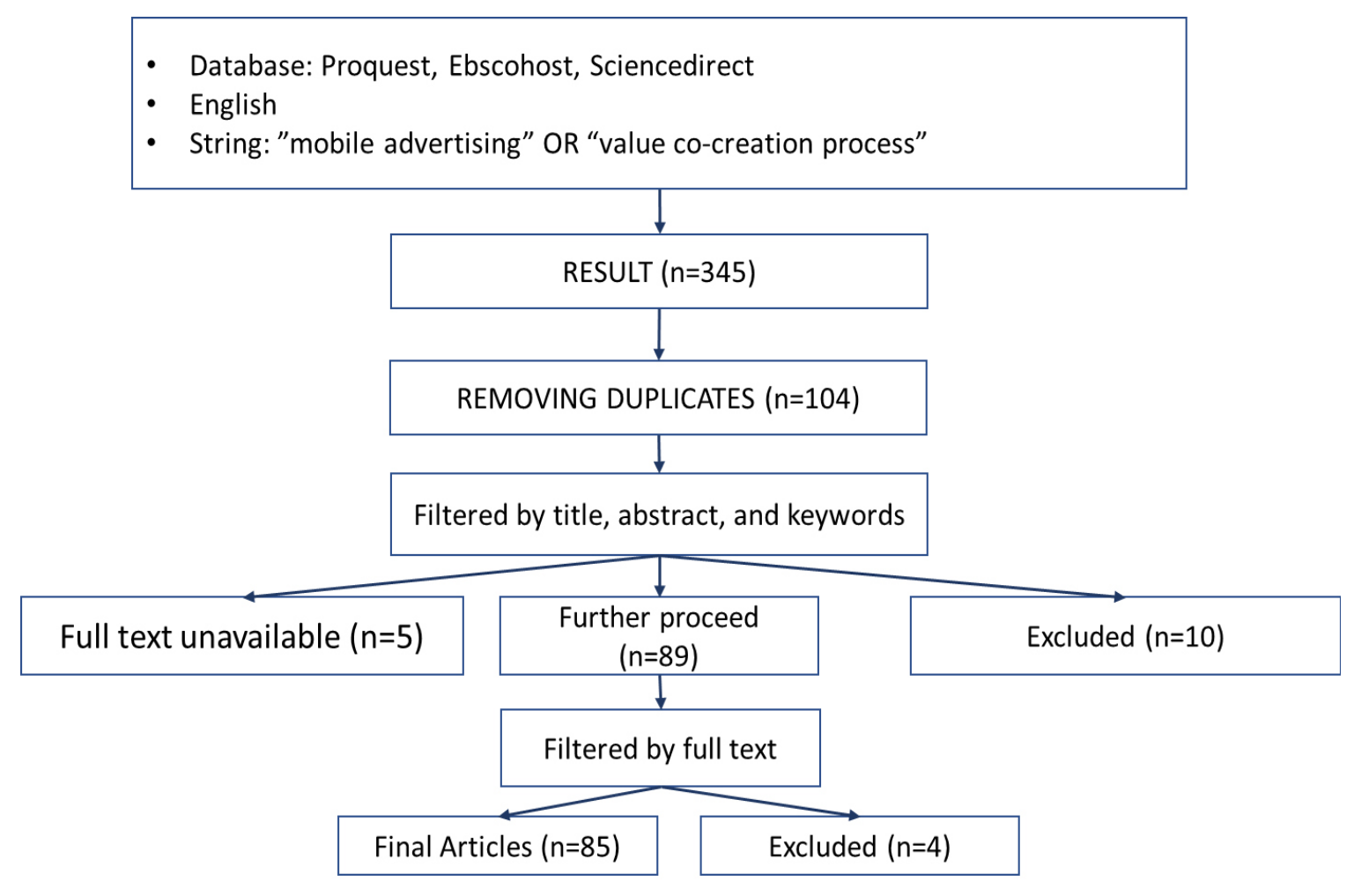

Figure 2. Method of Materials

\section{RESULTS}

Based on the model of attribute research and the benefits of acceptance attitude towards online ads (Korgaonkar and Wolin, 2007), click through rate (CTR) measurement model (Nihel, 2013), the cocreation of value exploring engagement behaviors in user generated content websites (Gangi, 2010), and consumer engagement model (Vivek, 2009) the frame of thought in this study is based on several theories as follows:

\section{Theory of Usability and Satisfaction}

Customer experience in mobile advertising will depend on the purpose and satisfaction they get from interaction using mobile advertising services. Customers will only buy products offered mobile advertising services that are appropriate and meet the customer's wishes. The main purpose of customers to join in using mobile advertising services is classified in four types, namely: Purpose of information acquisition (knowledge acquisition): is a goal that reflects utilitarian or pragmatic values that customers get something from their interactions in mobile advertising services; Purpose of socialization includes values related to interpersonal relationships facilitated by interactions in mobile advertising services; Purpose of fun and entertainment (entertainment): is a hedonistic goal, reflecting the value of pleasure obtained by customers from the results of their interactions. The purpose of fun and entertainment includes aspects of fun, entertainment, escape, and the like; Purpose of fame and influence: reflects the values obtained from the results of customer interaction in mobile advertising services. The values gained relate to self-esteem, fame, confidence, and the potential to influence other members through information or actions that benefit others.

\section{Theory of Information Searching Effectiveness}

This model refers to the concept of ongoing searching in consumer behavior literature. The goal is to test the effectiveness impact of customers in finding the information needed when customers access mobile advertising services, as well as the effectiveness of their attitude and perception of products and organizations/ companies. Ongoing searching is defined as the free search for information by consumers against their needs. 


\section{Theory of Communication}

\section{Interactivity}

The focus of customer interactivity is on the responses earned, i.e. the time it takes to get answers, the number of responses earned when posting questions and the general perception of other people's responses.

\section{Perceived homophily}

Most human communication occurs between sources and recipients who have similarities (congruent). Homophily is defined as a degree of congruent between individuals in certain attributes, such as demographic similarities, beliefs or beliefs. Customers who have homophily levels with other members of mobile advertising services tend to have positive perceptions or feel benefited from interactions between them. Danaher and Mullarkey (2003) stated that factors influencing recall ads such as customer characteristics, ad repetition, duration of ads appearing, publicity campaigns, special moments, curiosity, and innovative advertising strategies. The main finding is that customer characteristics become the main reference for advertisers in marketing their products.

\section{User activity level}

The higher the level of activity of customers with their mobile phones, the greater the perceived value of information exchange and interaction for those customers.

\section{Theory of Consumer Engagement}

Defined as the contribution of consumers in the retrieval or exploration of content in the online community site (Kankanhalli et al. 2005; Li et al. 2011). The more consumer involvement will provide opportunities for the formation of greater co-creation value and the more valuable the mobile advertising service. User engagement is measured using measurement methods adapted from Vivek (2009) with measurement attributes:

\section{Enthusiasm}

The dimension of enthusiasm signifies excitement or a strong passion about engagement. Consumers who engage will feel happy to actively participate with the company's activities. Customer excitement in community engagement and maintenance shows a high level of enthusiasm to bring up new ideas (Langston, 2008). Enthusiastic consumers tend to explore offers from advertisers enthusiasm makes consumers feel more alive while they engage in corporate activities.

\section{Conscious participation}

Participation awareness includes the dimensions of awareness and activity. Consciousness is defined as thinking about patterns of interaction, comparison between partners in a relationship (Acitelli 1992). The higher the intensity of consumer engagement, the further the consumer interacts and engages in it. The activity represents the involvement of consumers who participate physically in the activities provided by the company.

\section{Social interaction}

The dimension of interaction is the exchange of ideas, thoughts, and feelings between consumers about consumer participation and the focus of their involvement. The higher the level of engagement, the more interested participants will be in exchanging experiences, thoughts and feelings with other consumers. Interactions play a very significant role in cases where engagement results in social benefits, compared to situations where it results in more personalized benefits.

\section{Theory of Attitude Toward Online Ads}

Korgaonkar and Wolin (2002) explain the difference between internet users who have characteristics of heavy user type and light user type, it is concluded that heavy users hold strong beliefs about attitudes towards advertising on the internet that may have stronger purchasing intentions compared to lighter users, heavy users believe the ads displayed on the internet can be trusted, entertaining, informative, and helpful; but it tends to be difficult to understand. They feel that the ads shown on the internet are a good thing, quite important, and that it reduces the cost of products from advertisers, but those ads should be made specific according to customer characteristics. Similarly, Ducoffe (1996) found that internet advertising can be considered informative, entertaining, useful, valuable, and important. 


\section{Theory of Click Through Rate}

CTR is a percentage form to calculate between the number of clicks and the number of ad units shown. As explained by Nihel (2013), CTR analysis of banner ads is believed to be the most common way to attract customers and engage them in the selection of brands or products from advertisers. CTR measurement has become important for advertisers to measure the effectiveness of these websites. The same researcher explained the factors that affect CTR are the contextual factors of the ads shown. The supporting factors of CTR according to Nihel (2013) are banner size, animation, length of ad duration and logo, color, and image, all of these things affect the direct response of customers in terms of measuring the effectiveness of CTR.

\section{Theory of Value Co-creation}

Value co-creation is defined as a shared benefit for both organizations/companies and customers from the results of their involvement and interaction in mobile advertising services. Gangi (2010) stated that cocreation value is mutually beneficial to both parties, both companies and customers, such relationships include:

\section{Connection with the company}

The relationship with the Company is the emotional bond of the customer with a company. Customers will maintain positive, frequent, timely and accurate communication with business companies.

\section{Goodwill}

Goodwill in the context of the business as an advantage or support that the business has acquired through the brand and good reputation of the company. Goodwill is a form of feeling of support, interest or attention gained by giving something. High consumer engagement will have a high level of goodwill towards the organization. Goodwill measurement adapted from Bove et al. (2008), covers dimensions of virtue, trust, and credibility.

Intent to do business

The tendency of business shows the attitude of consumers to build a business with the company or maintain an existing business relationship with the company.
Affective commitment

Affective commitment is a psychological attachment that motivates consumers to establish relationships with the company because it is in accordance with its wishes. WOM is a way of informal communication between people, namely between communicators and non-commercial recipients about brands, products, companies, or services (Vivek, 2009). The power of word of mouth (WOM) includes aspects of fun relationships, enthusiasm, new experiences, recommendations to others, and a good atmosphere.

Based on the theoretical framework above, this study uses the frame of thought as seen in Figure 3. Based on the literature review and conceptual framework of this article (Figure 3) the following hypotheses need to be proposes in this paper (Table 1).

\section{Managerial Implications}

Improving the capabilities of companies and customers by continuing mobile advertising services, where these services wheezenew services in the telecommunications industry. Provide customer education about the usefulness of mobile adverting services, where the service is based on profiling customers so that customers are not sorted into the existence of this service. Enhance the capabilities of companies and customers to have open dialogue, giving customers a greater role to share and transparency for long-term translation. This brief comparative overview of literature review and research of this paper has identified some potential areas of how to value co-creation have a strong relationship in mobile advertising of telecommunication industry in Indonesia.

\section{CONCLUSIONS AND RECOMMENDATIONS}

\section{Conclusions}

The conceptual model presented two sides of the same coin which is important to understand how value cocreation is developed from the perspective of the consumers and service providers. By understanding the antecedents of value co-creation in telecommunication industry, with specific in Mobile Advertising from the perspective of the consumers and how present service providers are attracting their customers in this area, future application of the Mobile Advertising channel can 
be better planned to benefit the consumer and service providers. In other words, one needs to understand the relationship between attitude toward online ads and Mobile Advertising channels before trying to assess Mobile Advertising effectiveness.

Based on the conceptual framework: customer purposes, information searching effectiveness, and communication, haveeffects on consumer engagement, CTR, and attitude toward online ads. Then consumer engagement, CTR, and attitude toward online ads also have effects to value co creation. We propose attitude toward online ads also has effect as an intervening variable to CTR and consumer engagement.

This brief comparative overview of the literature review and research of this paper has identified some potential areas of how to value co-creation have a strong relationship in mobile advertising of telecommunication industry in Indonesia. Although there are lots of questions, discussions and debates regarding to still not yet explored other potential factors (technology enabler, media seller, privacy issues and legislation) that may influence the development of trust towards Mobile Advertising channel. Of course, further research regarding the other areas of improvement in the regulation needs to be further elaborate.

\section{Recommendations}

Based on the conclusion, it is recommended that the telecommunication operator should give support especially in developing related to mobile advertising industry so that all the industry in general and specially in mobile advertising can get the results. Although there are lots of questions, discussions and debates regarding to still not yet explored other potential factors (technology enabler, media seller, privacy issues and legislation) that may influence the development of trust towards Mobile Advertising channel. Of course, further research regarding the other areas of improvement in the regulation need to be further elaborate.

\section{REFERENCES}

Acitelli L. 1992. Gender differences in relationship awareness and marital satisfaction among young married couples. Personality and Social Psychology Bulletin 18(1): 102-110. https://doi. org/10.1177/0146167292181015.
Achadinha NMJ, Jama L, Nel P. 2014. The drivers of consumers' intention to redeem a push mobile coupon. Behaviour \& Information Technology 33(12): 1306-1316. https://doi.org/10.1080/014 4929X.2014.883641.

AluriA, Slevitch L, Larzelere R. 2015. The effectiveness of embedded social media on hotel websites and the importance of social interactions and return on engagement. International Journal of Contemporary Hospitality Management 27(4):670-689. https://doi.org/10.1108/IJCHM09-2013-0415.

[BPS] Badan Pusat Statistik Jakarta Pusat, 2019. Statistik Indonesia Tahun 2019. Jakarta: Badan Pusat Statistik.

Baltas G. 2003. Determinants of internet advertising effectiveness: An empirical study. International Journal of Market Research 45(4): 505-513. https://doi.org/10.1177/147078530304500403.

Bei, Ju. 2013. A proposed cross-cultural examination of online advertising effectiveness in China and the UK. International Journal of Business and Management 8(6):34-49.https://doi.org/10.5539/ ijbm.v8n6p34.

Chung KC, Holdsworth DK. 2012. Culture and behavioural intent to adopt mobile commerce among the Y Generation: comparative analyses between Kazakhstan, Morocco and Singapore. Young Consumers 13(3):224-241. https://doi. org/10.1108/17473611211261629

Danaher PJ, Mullarkey GW. 2003. Factors affecting online advertising recall: A study of students. Journal of Advertising Research 43(3): 252-267. https://doi.org/10.2501/JAR-43-3-252-267.

Ducoffe. 2006. Interdisciplinary, team - taught, undergraduate business course; The impact of integration. Journal of Management Education 30: 276-294

Erat P, Desouza K, Jugel A, Kurzawa M. 2006. Business customer communities and knowledge sharing: exploratory study of critical issues. European Journal of Information Systems 15 (5): 511-524. https://doi.org/10.1057/palgrave.ejis.3000643.

Fremlin J. 2012. Sense of community in a mediated world [disertation]. California: The Faculty of Fielding Graduate University.

Gangi P. 2010. The co-creation of value exploring engagement behaviours in user-generated content websites [disertation]. United States: The Florida State University College of Business.

Goldsmith RE, LaffertyBA, Newell SJ.2000. Theimpact 
of corporate credibility and celebrity credibility on consumer reaction to advertisements and brands. Journal of Advertising 29(3): 43-54. https://doi.org/10.1080/00913367.2000.106736 16.

Ho SY, Kevin KWH. 2008. The Effects of Web Personalization on Influencing Users' Switching Decision to a New Website. Pacis 2008 Proceedings. Paper 67.

Holbrook M. 2006. 'Co-Creation Versus CoDestruction' in The Service Dominant Logic of Marketing: Dialog, Debate and Directions, Robert F. Lusch and Stephen L. Vargo. Eds. Publisher: M. E. Sharpe

Joshi A, Sharma S. 2004. Customer knowledge development: antecedents and impact on new product performance. Journal of Marketing 68 (4): 47-59. https://doi.org/10.1509/ jmkg.68.4.47.42722.

Jun JW. 2011. Consumer responses to creative platform of the internet advertising. The Web Journal of Mass Communication Research April 2011

Kankanhalli A, Tan B, Wei K. 2005. Contributing knowledge to electronic knowledge repositories: an empirical investigation. MIS Quarterly 29 (1): 113-143.

Kim NY, Sundar SS. 2010. Relevance to the rescue: can 'Smart Ads' reduce negative response to online Ad clutter?, Journalism \& Mass Communication Quarterly 87(2): 346-362. https://doi.org/10.1177/107769901008700208.

Korgaonkar P, Wolin LD. 2002. Web usage, advertising, and shopping: relationship patterns. Internet Research: Electronic Networking Applications and Policy 12(2): 191-204.

Kotler P, Armstrong G. 2018. Principles of Marketing. 17th ed. New Jersey: Pearson Education, Inc.

Kotler P, Keller KL. 2016. Marketing Management 15e. England: Pearson Education Limited.

Langston E. 2008. The effect of virtual participation in a community of practice: a study of harnessing knowledge in a virtual world [disertation]. Minneapolis: Capella University.

Li C, Bernoff J. 2011. Groundswell, Expanded and Revised Edition: Winning in a World Transformed by Social Technologies, 2011. UK: Harvard Business School Press.

Lin et al. 2018. Value co-creation on social media examining the relationship between brand. International Journal of Contemporary Hospitality Management 30(4):2153-2174. https://doi.org/10.1108/IJCHM-08-2016-0484.

Menon S, Soman D. 2002 Managing the power of curiosity for effective web advertising strategies. Journal of Advertising 31: 1-14.

Muk A, Chung C. 2015. Applying the technology acceptance model in a twocountry study of SMS advertising. Journal of Business Research 68(1): $1-6$.

Newman. 2004. Fast algorithm for detecting community structure in networks. Journal of Software Engineering and Applications 1(1). https://doi. org/10.1103/PhysRevE.69.066133.

Nihel. 2013. The effectiveness of internet advertising through memorization and click on a banner. International Journal of Marketing Studies 5(2):93-101. https://doi.org/10.5539/ijms. v5n2p93.

Schlosser AE, Shavitt S, Kanfer A. 2009. Survey of Internet users' attitudes toward Internet advertising. Journal of Interactive Marketing 13(3): 34-54.

Szmigin. 2005. Customer perspectives on the role and importance of branding in Irish retail financial services. International Journal of Bank Marketing 23(1):8-27. https://doi. org/10.1108/02652320510577348.

Tassi P. 2013. Facebook's advertising is starting to spiral out of control. www.forbes.com/sites/ insertcoin/2013/07/01/facebooks-advertising-isstarting-to-spiral-out-of-control/ [16 Jul 2014].

Vivek S. 2009. A Scale of Consumer Engagement.

[Disertation]. Alabama: Department of Management and Marketing in the Graduate School of The University of Alabama.

Wagner C, Majchrzak A. 2007. Enabling customercentricity using wiki the wiki way. Journal of Management Information Systems 23(3):17-43.

Zhang K, Katona Z. 2012. Contextual advertising. Marketing Science 31(6):980-994. 